\title{
INFLUÊNCIA DA QUALIDADE MICROBIOLÓGICA DA ÁGUA SOBRE A QUALIDADE DO LEITE
}

\author{
Influence of the water microbiological quality on the milk quality
}

\author{
RAMIRES, C.H. ${ }^{1}$; BERGER, E.L. ${ }^{2}$; ALMEIDA, . $^{3}$ \\ ${ }^{1}$ Universidade Federal do Paraná. \\ ${ }^{2}$ Batavo Cooperativa Agroindustrial. \\ ${ }^{3}$ Departamento de Zootecnia da Universidade Federal do Paraná \\ Endereço para correspondência: Rodrigo de Almeida - ralmeida@ufpr.br.
}

\section{RESUMO}

O objetivo desse estudo foi o de verificar a influência da qualidade microbiológica da água (coliformes fecais e totais e contagem total) sobre os valores de contagem de células somáticas (CCS) e contagem bacteriana total (CBT), indicativos de qualidade do leite. Analisou-se a qualidade da água e do leite de 162 propriedades na região dos Campos Gerais (PR), entre os meses de fevereiro a maio de 2007. De acordo com os resultados da análise da água, $62 \%$ das propriedades estão fora do padrão de potabilidade de água estabelecido pelo Ministério da Saúde. A média e o desvio-padrão para os parâmetros analisados foram de $224 \pm 387$ coliformes totais (NMP/100mL), $187 \pm 354$ coliformes fecais (NMP/100mL), 0,05 $\pm 0,08 \times 10^{4}$ contagem total (UFC/mL), $399.000 \pm 170.000$ contagem de células somáticas (células $/ \mathrm{mL}$ ) e 3,85 $\pm 8,6 \times 10^{4}$ contagem bacteriana total (UFC/mL). As três variáveis de qualidade de água apresentaram correlações altas e significativas $(P<0,01)$ entre si. Os parâmetros de qualidade do leite, CCS e CBT, apresentaram uma significativa $(P<0,01)$, mas moderada correlação $(r=0,22)$. Contudo, as correlações entre as variáveis de qualidade de água e de leite não foram significativas $(P>0,05)$. Houve efeito significativo $(P<0,01)$ do sistema de ordenha empregado na propriedade sobre os valores de CBT, indicando que fazendas com ordenha em salas de ordenha produziram leite com menor $(P<0,01)$ contagem do que propriedades com ordenha em sistema canalizado. A qualidade microbiológica da água não influenciou a qualidade do leite, indicando que valores altos de CCS e CBT ocorreram por falhas na higienização no processo de obtenção do leite e dos equipamentos nas propriedades.

Palavras-chave: coliformes fecais, coliformes totais, contagem bacteriana total, células somáticas.

\section{ABSTRACT}

The objective of this study was to verify the influence of the water microbiological quality (fecal and total coliforms and total counting) on the somatic cell count (SCC) and total bacterial count (TBC), which are indicative of milk quality. Water and milk quality from 162 herds in the Campos Gerais county, Parana State, were analyzed, between February and May, 2007. According to the water analysis, $62 \%$ of the farms were not in agreement with the water potability standards established by Brazilian Health Ministry. Means and standard deviations of analyzed parameters were $224 \pm 387$ total coliforms (MPN/100mL), $187 \pm 354$ fecal coliforms (MPN/100mL), $0.05 \pm 0.08 \times 10^{4}$ total counting (CFU/mL), 399,000 $\pm 170,000$ somatic cell count (cells $/ \mathrm{mL}$ ) and $3.85 \pm 8.6 \times 10^{4}$ total bacterial count $(\mathrm{CFU} / \mathrm{mL})$. Water quality parameters showed high and significant correlations among them $(P<0.01)$. Milk quality variables $(S C C$ and $T B C)$ had showed a significant $(P<0.01)$ but moderate correlation $(r=0.22)$. However, the correlations among water quality variables and milk quality parameters were not significant $(P>0.05)$. There was a significant effect $(P<0.01)$ of the milking system on TBC values, indicating that farms with milking parlor had produced milk with lower $(P<0.01)$ total bacterial count than herds with canalized milking system. Water microbiological quality did not affect the milk quality, indicating that high values of SCC and TBC were due hygienic failures in the milk obtaining process and equipments in the herds.

Key words: fecal coliforms, somatic cell, total bacterial count, total coliforms. 


\section{INTRODUÇÃO}

A obtenção de leite de boa qualidade é dependente de vários fatores como o estado sanitário do rebanho, limpeza dos equipamentos e utensílios de ordenha, a higiene do local de sua obtenção, bem como da qualidade da água utilizada na propriedade. Esse fator é importante, visto que a água pode ser veículo de agentes patogênicos tanto para seres humanos como para animais.

Pesquisas anteriores demonstraram correlação entre a qualidade da água e o surgimento de mastites em bovinos leiteiros, elevando desta forma, a contagem de células somáticas (CCS) no leite. Schukken et al. (1991) afirmaram que o risco de ocorrer mastite por Staphylococcus aureus aumenta quando se utiliza água não tratada no processo de obtenção de leite ou quando a água de lavagem do úbere está contaminada por coliformes.

Já outros pesquisadores verificaram associação entre a qualidade microbiológica da água utilizada na produção de leite e a ocorrência de mastite nos rebanhos. Hutabarat et al. (1985) determinaram que a incidência de mastite foi de $22,4 \%$ quando a água era de boa qualidade e de $38,0 \%$ quando de má qualidade.

Para avaliar as condições sanitárias da água utilizam-se bactérias do grupo coliforme que atuam como indicadores de contaminação de origem fecal, pois ocorrem em grande número na flora intestinal humana e de animais de sangue quente. A presença de coliformes na água indica contaminação, com o risco potencial da presença de organismos patogênicos e sua ausência evidencia uma água bacteriologicamente potável.

Segundo Lagger et al. (2000), a contaminação bacteriana da água é muito grave, porque afeta a saúde da família rural e do rebanho, a higiene e a desinfecção dos equipamentos de ordenha. Isto porque após o enxágue final com essa água, ocorrerá recontaminação dos equipamentos, ao invés do efeito desejado.

No meio acadêmico há um número reduzido de estudos quanto à qualidade da água utilizada na dessedentação de animais (água de bebida) relacionada a nascentes, fontes e reservatórios (Amaral et al., 2003a, 2003b, 2004), bem como poços e bebedouros (Souza, 1983). Entretanto o número de referências é ainda menor quanto à influência da qualidade dessas águas na qualidade do leite cru produzido. Medeiros e Souza (2008) estudaram a análise microbiológica da água utilizada na ordenha em propriedades leiteiras no estado de São Paulo, porém não correlacionaram com a qualidade do leite. Picinin (2003) avaliou a influência da qualidade da água e a qualidade do leite em 30 propriedades no estado de Minas Gerais, porém não gerou correlação entre as mesmas.

Este estudo teve como objetivo identificar propriedades com problemas nas contagens de coliformes fecais e totais e na contagem total, através da análise microbiológica da água, e estimar as correlações entre essas variáveis de qualidade de água com os valores de contagem de células somáticas (CCS) e contagem bacteriana total (CBT) no leite. Como objetivo secundário verificou-se a influência dos sistemas de ordenha e do volume de produção de leite nos parâmetros indicativos de qualidade do leite.

\section{MATERIAL E MÉTODOS}

Este trabalho foi realizado na região dos Campos Gerais, estado do Paraná, avaliando a qualidade da água de 162 propriedades leiteiras da Batavo Cooperativa Agroindustrial, para pesquisa de coliformes fecais, de coliformes totais e contagem total, no período de fevereiro a maio de 2007. 
As amostras de água foram coletadas em torneiras na sala do tanque de leite, buscando representar a água que é utilizada na limpeza e higienização dos utensílios e equipamentos de ordenha nas propriedades. Quando não havia torneira na sala de leite, buscava-se um ponto que representasse a água da propriedade.

$O$ frasco de coleta $(20 \mathrm{~mL})$ esterilizado era aberto somente no momento da coleta, com rigorosa assepsia. Deixava-se escorrer um pouco de água, para depois iniciar a coleta. Em seguida, os frascos eram transportados sob refrigeração, evitando a multiplicação bacteriana. As amostras eram encaminhadas ao Laboratório Labmark-Labvet, em Carambeí-PR, contratado pela cooperativa para as análises.

Foi utilizada a metodologia da Instrução Normativa $\mathrm{n}$ ㅇ. 62 do Ministério da Agricultura, Pecuária e Abastecimento (MAPA), de 23 de agosto de 2003, para determinação do número mais provável (NMP) de coliformes totais por $100 \mathrm{~mL}$ de amostra, utilizando-se do meio caldo lactosado verde brilhante e bile $2 \%$ (VBB) com incubação a $35 \pm 0,5^{\circ} \mathrm{C}$ durante 24-48 horas. Todas as determinações foram realizadas em triplicatas.

A quantificação de Coliformes Fecais (CF) consistiu-se na transferência das culturas de todos os tubos positivos para coliformes totais para tubos contendo E.C. Medium, que foram incubados durante $24 \pm$ 2 horas a $44,5 \pm 0,2^{\circ} \mathrm{C}$, em banho-maria com agitação e temperatura constantes.

Para a Contagem Total (CT) de bactérias aeróbias mesófilas foi semeado 1 $\mathrm{mL}$ de cada diluição em placas de petri, em duplicata, acrescentando-se a seguir 18 a $20 \mathrm{~mL}$ de ágar padrão para contagem (Difco). Após incubação a $37^{\circ} \mathrm{C}$ por 48 horas, foi feita a contagem de unidades formadoras de colônias (UFC) pelo método de contagem em placas.

Os parâmetros de qualidade do leite foram analisados junto ao Programa de Análise de Rebanhos Leiteiros do Paraná
(PARLPR) da Associação Paranaense de Criadores de Bovinos da Raça Holandesa (APCBRH), referente ao controle de abril de 2007. A contagem de células somáticas foi determinada no equipamento Somacount (Bentley Instruments $\AA$ ), através da citometria de fluxo, enquanto que a contagem bacteriana total foi determinada no sistema de UFCs contagem padrão em placas conforme determina a Instrução Normativa 51.

A análise estatística foi realizada como segue: para o estudo da variável volume de produção, dividiu-se a produção de leite diária em três classes, sendo: 58 produtores com produção até 599 litros de leite/dia, 45 produtores com produção entre 600 e 1199 litros de leite/dia e 59 produtores com produção acima de 1200 litros de leite/dia.

Já na análise dos sistemas de ordenha consideraram-se três possibilidades: ordenha balde ao pé (47 produtores), sistema canalizado em estábulo (30 produtores) e ordenha em salas de ordenha (espinha de peixe, paralela, tandem e poligonal), totalizando 85 produtores.

Os valores de contagem total da água e CCS e CBT do leite foram transformados para log base 10, com o objetivo de normalizar a distribuição dos dados.

Os resultados foram submetidos à análise estatística descritiva e correlações simples de Pearson foram estimadas pelo procedimento CORR do pacote estatístico SAS (2001). A significância dos efeitos fixos de volume de produção e sistema de ordenha foi determinada por análise de variância e as médias ajustadas foram comparadas pelo Teste de Tukey a $1 \%$ e a $5 \%$ de significância, através do procedimento GLM do SAS (2001).

\section{RESULTADOS E DISCUSSÃO}

Neste trabalho, a qualidade microbiológica da água das propriedades analisadas foi preocupante. De acordo com os dados 
Tabela 1 - Frequência absoluta e relativa de propriedades leiteiras de acordo com os valores de coliformes fecais, coliformes totais e contagem total nas amostras de água.

\begin{tabular}{lccccccc}
\hline & \multicolumn{2}{c}{ Coliformes Fecais } & \multicolumn{2}{c}{ Coliformes Totais } & \multicolumn{3}{c}{ Contagem Total } \\
\hline Variação & №. obs. & Freq. (\%) & №. obs. & Freq. (\%) & Variação & $\begin{array}{c}\text { № } \\
\text { obs. }\end{array}$ & $\begin{array}{c}\text { Freq. } \\
(\%)\end{array}$ \\
\hline 0 (Padrão) & 70 & 43 & 62 & 38 & $0-500$ & 106 & 66 \\
$1-500$ & 73 & 45 & 76 & 47 & $501-1000$ & 28 & 17 \\
$501-1000$ & 0 & 0 & 0 & 0 & $1001-2000$ & 15 & 9 \\
Acima 1000 & 19 & 12 & 24 & 15 & Acima 2000 & 13 & 8 \\
\hline Total & $\mathbf{1 6 2}$ & $\mathbf{1 0 0}$ & $\mathbf{1 6 2}$ & $\mathbf{1 0 0}$ & Total & $\mathbf{1 6 2}$ & $\mathbf{1 0 0}$ \\
\hline
\end{tabular}

obtidos, do total de 162 fazendas, 100 propriedades estavam fora dos padrões de potabilidade da água estabelecidos pelo Ministério da Saúde (Portaria no. 518 de 23 de março de 2004: "Estabelece os procedimentos e responsabilidade relativa ao controle e vigilância da qualidade da água para consumo humano e seu padrão de potabilidade e dá outras providências").

Das propriedades estudadas, 100 estavam fora do padrão para coliformes totais, 92 para coliformes fecais e 56 para contagem total. Esta é uma informação alarmante, já que a água dessas propriedades não estava adequada para ser usada na limpeza do equipamento de ordenha e do tanque de expansão ou outros utensílios.

Do total, 56 (35\%) estavam fora do padrão nos três parâmetros analisados, 36 $(22 \%)$ em dois parâmetros e 8 (5\%) com alteração em um único parâmetro. Portanto, das propriedades estudadas apenas 62 (38\%) apresentaram padrão de potabilidade para água.

Os valores altos de coliformes totais e fecais encontrados no ponto de saída podem indicar contaminação na fonte ou na caixa d'água por resíduos de fezes ou ainda por erros prévios (localização da fonte) na hora da instalação dessas caixas. Para cada parâmetro de qualidade de água analisado foram estimadas as frequências absolutas e relativas de propriedades por faixa de variação (Tabela 1).

Calcularam-se as médias e respectivos desvios-padrão para os diversos parâmetros de qualidade de água e de leite analisados: $224 \pm 387$ coliformes totais, $187 \pm 354$ coliformes fecais, $0,05 \pm 0,08 x$ $10^{4}$ contagem total, $399.000 \pm 170.000$ contagem de células somáticas e 3,85 \pm $8,6 \times 10^{4}$ contagem bacteriana total do leite.

As variáveis de água (coliformes totais e fecais e contagem total) apresentaram alta correlação $(P<0,01)$ entre elas; o mesmo ocorreu para os parâmetros de qualidade do leite (CCS e CBT) que foram significativamente $(P<0,01)$ correlacionadas. Contudo, as correlações entre as variáveis de qualidade de água e de leite não foram significativas $(P>0,05)$, indicando uma não associação entre a potabilidade da água e a qualidade do leite produzido (Tabela 2).

A falta de associação entre qualidade da água e do leite sugere que nessas propriedades, altos valores de CBT podem ser atribuídos aos processos inadequados na obtenção de leite de qualidade, em especial para as condições de higiene antes, durante e após a ordenha ou ainda na higienização dos tanques, caracterizada pela utilização de produtos de limpeza insuficientes ou não apropriados.

Pode-se afirmar que nas propriedades estudadas a CCS dependeu mais de outros fatores, tais como estádio da lactação, idade dos animais, estação do ano, manejo 
Tabela 2 - Correlações entre os parâmetros microbiológicos da água com os parâmetros indicativos da qualidade do leite.

\begin{tabular}{lccccc}
\hline & $\begin{array}{c}\text { Coliformes } \\
\text { totais }\end{array}$ & $\begin{array}{c}\text { Coliformes } \\
\text { fecais }\end{array}$ & $\begin{array}{c}\text { Log Contagem } \\
\text { Total }\end{array}$ & Log CCS & Log CBT \\
\hline Coliformes totais & 1,00 & 0,92 & 0,44 & 0,03 & 0,03 \\
Coliformes fecais & - & 1,00 & 0,43 & 0,08 & 0,01 \\
Log contagem total & - & - & 1,00 & $-0,05$ & $-0,01$ \\
Log CCS & - & - & - & 1,00 & 0,22 \\
Log CBT & - & - & - & - & 1,00 \\
\hline
\end{tabular}

de ordenha, etc., do que da qualidade microbiológica da água, isto é, neste caso, a água não foi um fator decisivo.

Os resultados mostraram que as variáveis indicativas de qualidade do leite foram moderadamente associadas entre si $(r=0,22)$. Esta estimativa foi muito próxima a correlação entre CCS e CBT encontrada por Gonzalo et al. (2006), $(r=0,23)$ que analisaram fontes de variação da CBT em leite ovino na Espanha.

Tabela 3 - Contagem bacteriana total do leite e sistema de ordenha.

\begin{tabular}{|c|c|}
\hline Sistema de ordenha & LogCBT \\
\hline Balde ao pé & $1,07^{\mathrm{ab}}$ \\
\hline $\begin{array}{l}\text { Canalizado } \\
\text { Sala de Ordenha } \\
\text { (Mecânica) }\end{array}$ & $\begin{array}{l}1,34^{b} \\
0,87^{a}\end{array}$ \\
\hline
\end{tabular}

Os resultados indicaram que não houve efeito significativo $(P>0,05)$ para as variáveis volume de produção e sistema de ordenha sobre os três parâmetros de qualidade da água e CCS. Para a variável CBT verificou-se efeito significativo $(P<0,01)$ do sistema de ordenha adotado.

Em relação à contagem de células somáticas, não foi observado efeito significativo $(P>0,05)$ entre o sistema de ordenha e o número de células somáticas. Isto indica, para esta região estudada, que não é o tipo de equipamento de ordenha que determina o aumento ou a diminuição da contagem de células somáticas.
Também foi verificado que não houve efeito significativo $(P>0,05)$ do volume de produção da propriedade sobre o número de células somáticas. Esses resultados diferiram daqueles encontrados por Emanuelson e Funke (1991), que relataram maior incidência de mastite em rebanhos de maior produção de leite. Por outro lado, Ott et al. (1999) observaram decréscimo na CCS com a evolução no tamanho do rebanho.

Para os valores de CBT verificou-se efeito significativo $(P<0,01)$ do sistema de ordenha empregado na propriedade. Os resultados indicaram que fazendas com ordenha em salas de ordenha (mecânica) produziram leite com menor $(P<0,01)$ contagem bacteriana total do que propriedades com sistema canalizado. As propriedades com sistema de ordenha balde ao pé apresentaram valores intermediários e não distintos $(P>0,05)$ de CBT em relação aos dois sistemas de ordenha já mencionados (Tabela 3 ).

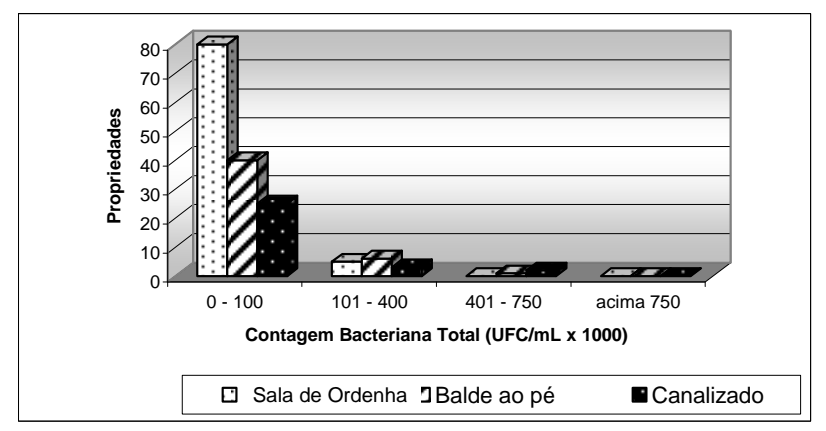

Figura 1 - Tipo de equipamento utilizado na ordenha distribuído em função da contagem bacteriana total no leite. 
Nesse caso, pode-se afirmar que a falta de higiene na obtenção do leite e a limpeza ineficiente dos equipamentos de ordenha e do tanque de expansão, podem alterar os valores finais de contagem bacteriana. A Figura 1 demonstra maior concentração de propriedades com ordenha em salas de ordenha na faixa de menor contagem bacteriana no leite (até $100.000 \mathrm{UFC} / \mathrm{mL}$ ).

$O$ efeito de volume de produção não apresentou significância $(P>0,05)$ sobre a contagem bacteriana total. Portanto, 0 volume de produção não determina a qualidade da matéria-prima, e sim, a associação entre a ordenha e o manejo do rebanho utilizado na propriedade.

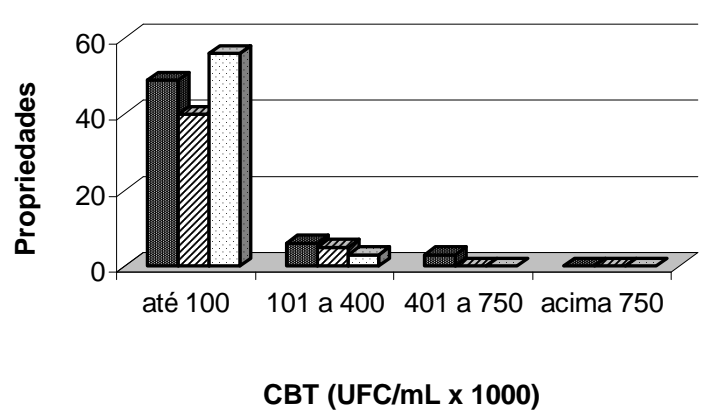

\footnotetext{
四 599 litros/dia

四600 a 1199 litros/dia

๑acima 1200 litros/dia
}

Figura 2 - Classes de produção de leite diária distribuída em função da contagem bacteriana total no leite.

A Figura 2 demonstra que das 162 propriedades incluídas neste estudo, 17 fazendas (ou 10,5\%) estavam acima do limite máximo de CBT estabelecido pela Instrução Normativa no 51/2002 (100.000 $\mathrm{UFC} / \mathrm{mL}$ de leite), limite máximo este que será exigido a partir de 01 de julho de 2011.

\section{CONCLUSÕES}

A qualidade microbiológica da água da maioria das propriedades não apresentou condições satisfatórias para uso na higienização dos equipamentos e consumo pelos animais e seres humanos, sugerindo a necessidade de implantação de um programa de melhoria de qualidade da água.

Altos valores de CCS e CBT ocorreram por falhas na higienização no processo de obtenção do leite e dos equipamentos nas propriedades.

Propriedades com ordenha mecânica em salas de ordenha apresentaram menores contagens bacterianas no leite (CBT).

\section{REFERÊNCIAS}

\author{
AMARAL, L. A.; NADER FILHO, A.; ROSSI \\ JÚNIOR, O.D. Ocorrência de Staphylococcus sp. \\ em água utilizada em propriedades leiteiras no \\ Estado de São Paulo. Arquivo Brasileiro de \\ Medicina Veterinária e Zootecnia, v.55, n.5, \\ 2003a.
}

AMARAL, L. A.; NADER FILHO, A.; ROSSI JÚNIOR, O.D. Água de consumo humano como fator de risco à saúde em propriedades rurais. Revista de Saúde Pública, v.37, n.4, 2003b.

AMARAL, L. A.; ROMANO, A.P.M.; NADER FILHO, A.; ROSSI JÚNIOR, O.D. Qualidade da água em propriedades leiteiras como fator de risco à qualidade do leite e à saúde da glândula mamária.

Arquivo do Instituto Biológico, v.71, n.4, p.417421, 2004.

BRASIL Ministério da Agricultura. Instrução Normativa ํ․ 62 de 23 de agosto de 2003.

Métodos Analíticos oficiais para análises microbiológicas para controle de produtos de origem animal e água. Brasília. Ministério da Saúde. Diário Oficial da União, Brasília, DF, 23 ago. 2003. Disponível em:

$<$ http://extranet.agricultura.gov.br/sislegisconsulta/consultarLegislacao. do?operacao=visualiza rid=2851 $>$. Acesso em: 02/05/2007.

BRASIL Ministério da Agricultura. Portaria ํ․ 101 de 11 de agosto de 1993. Métodos analíticos oficiais para análise de produtos de origem animal e seus ingredientes II: métodos físicos e químicos. Diário Oficial da União, Brasília, DF, 17 ago.1993. Seção 1. 89p. Disponível em http://www.extranet.agricultura.gov.br/sislegis- 
consulta/consultarLegislacao.do?operacao=visualiza r\&id=3876>. Acesso em: 12/04/2007.

BRASIL Ministério da Saúde. Portaria n‥ 518 de 23 de março de 2004. Estabelece os procedimentos e responsabilidade relativa ao controle e vigilância da qualidade da água para consumo humano e seu padrão de potabilidade e dá outras providências. Diário Oficial da União, Brasília, DF. 26 mar. 2004. Seção 1. Disponível em: <http://potal.saude.gov.br/portal/arquivos/pdf/portari a_518_2004.pdf>. Acesso em: 01/04/2007.

BRASIL. Ministério da Agricultura, Pecuária e Abastecimento. Instrução Normativa no. 51 de 18 de setembro de 2002. Regulamento Técnico de Produção, Identidade e Qualidade do Leite Tipo A, do Leite Tipo B, do Leite Tipo C, do Leite Pasteurizado e do Leite Cru Refrigerado e o Regulamento Técnico da Coleta de Leite Cru Refrigerado e de Transporte a Granel. Diário Oficial da União, Brasília, DF, 18 set. 2002. Seção 3. Disponível em: <

http://www.agricultura.gov.br/das/dipoa/in51.htm>. Acesso em: 01/04/2007.

EMANUELSON, U.; FUNKE, H. Effect of milk yield on relationship between bulk milk somatic cell count and prevalence of mastitis. Journal of Dairy Science, v.74, n.8, p.2479-2483, 1991.

FONSECA, L. F. L.; SANTOS, M. V. Qualidade do leite e controle de mastite. São Paulo: Lemos Ed., 2000. 175p.

GONZALO, C.; CARRIEDO, J.A.; BENEITEZ, E. Short Communication: Bulk tank total bacterial count in dairy sheep: Factors of variation and relationship with somatic cell count. Journal of Dairy Science, v.89, p.549-552, 2006.

HUTABARAT, T. S. P.; WITONO, S.; UNRULT, D. $H$. A. Preliminary study on management factors associated with mastitis and milk production losses in small holder hand milking dairy farms in Central Java, Indonésia. In: INTERNATIONAL SYMPOSIUM ON VETERINARY EPIDEMIOLOGY AND ECONOMIC, 1985, Singapura. Proceedings..., ISVEE, 1985. n.4, p.151-154.
LAGGER, J.R.; MATA, H.T.; PECHIN, G.H. La importancia de la calidad del água en producción lechera. Veterinaria Argentina, v.27, n.165, p.346354, 2000.

MEDEIROS, M. I. M.; SOUZA, L.C. Análise microbiológica da água utilizada na ordenha em propriedades leiteiras da região do médio Paranapanema - SP. Publicações em Medicina Veterinária e Zootecnia - PUBVET, v.2, n.20, 2008.

OTT, S.L.; WELLS, S.J.; SMITH, M.A. Bulk tank somatic cell counts of U.S. milk suplly, 1997. In: NATIONAL MASTITIS COUNCIL ANNUAL MEETING, 38., 1999, Arlington. Proceedings... Madison: National Mastitis Council, 1999. p.154156.

PICININ, L.C. A qualidade do leite e da água de algumas propriedades leiteiras de Minas Gerais. 2003. 89p. Dissertação (Mestrado em Tecnologia e Inspeção de Produtos de Origem Animal), Universidade Federal de Minas Gerais.

SAS. SAS/STAT User's Guide. Versão 8.2 SAS Int. Inc., Cary: NC, 2001.

SCHUKKEN, Y.H.; GROMMER, F.J.; VAN DER GREER, D. Risk factors for clinical mastitis in herds with low bulk milk somatic cell count. 2.Risk factors for Escherichia coli and Staphylococcus aureus. Journal of Dairy Science, v.74, p.826-832, 1991.

SOUZA, L. C.; IARIA, S. T.; PAIM, G. V.; LOPES, C. A. M. Bactérias coliformes totais e coliformes de origem fecal em águas usadas na dessedentação de animais. Revista de Saúde Pública, São Paulo, v.17, n.2, p.112-22, 1983. 